\title{
Black Cohosh
}

National Cancer Institute

\section{Source}

National Cancer Institute. Black Cohosh. NCI Thesaurus. Code C26647.

A triterpene-containing herb isolated from the roots and rhizomes of the plant Cimicifuga racemosa (also known as Actaea racemosa). While the mechanism of action of black cohosh is not completely understood, it appears to act as a selective estrogen receptor modulator. In vitro, this preparation has been shown to induce cell cycle arrest and caspase-dependent apoptosis of estrogen-sensitive breast cancer cells. ( $\mathrm{NCl04)}$ 